\title{
Interdependence: a new model for the global approach to disability
}

\author{
Nathan Grills ${ }^{\mathrm{a}}$
}

\begin{abstract}
${ }^{a}$ MBBS, MPH, DPhil, Associate Editor, CJGH; Nossal Institute of Global Health, University of Melbourne, Australia
\end{abstract}

Disability affects over one billion people worldwide. The World Health Organization (WHO) estimates that over $80 \%$ of individuals with disability live in low and middle income countries, where access to health and social services to respond to disability are "limited for all citizens." Disability is a growing area of importance in global health, which was demonstrated by the development and adoption of the UN Convention on the Rights of Persons with Disabilities 2006 (CRPD). ${ }^{2}$ Addressing disability is becoming more widely recognized as critical to promoting global health and development in low resource settings. To achieve many of the Sustainable Development Goals (2015), the international community will need to improve their response to disability and more effectively include people with disabilities. ${ }^{3}$ The Church and Christians working in global health can play an important role and are increasingly doing just this. A number of examples of recent national and global Christian disability movements are described in this journal. ${ }^{4}$ Field reports by Foxell, Flickner, and Paulraj demonstrate how short and long term disability ministries can be effective. There are also increasingly more courses available such as what Hall describes in Uganda to teach those Christians in global health how to be disability inclusive. ${ }^{5}$

The WHO defines disability as "the interaction between a person's impairments and the attitudinal and environmental barriers that hinder their full and effective participation in society on an equal basis with others." definition of disability highlights the challenge to the global health community and helps us understand the evolution of various paradigms or models of disability. This definition goes beyond mere healing or the medical model whereby the disability is seen in medical terms as something undesirable to be fixed or minimized. ${ }^{6}$ It also goes further than the charitable model, whereby people with disabilities are merely an object of help, an approach that the Church has perhaps championed with the best intentions and often with a positive impact. ${ }^{7}$ The WHO definition promotes a social model. That is one which requires societal attitudinal change and modification of disabling environments in order to facilitate those with disability to be independent and empowered.

The social model of inclusion is helpful, but I think it is inadequate and based on the western collectivist idea of promoting independence and autonomy as the ultimate endpoint within a society. We as Christians should go further. Sandin in this issue describes how explanatory models of disability and societal position can be thought of along the individualist-collectivist axis. $\mathrm{He}$ muses that "the ninth beatitude might have been blessed are those that do for themselves, for ..." because the dominant western individualist approach to disability has led to services that elevate independence and autonomy as the ultimate endpoint. However, such a paradigm is incongruent in a more collectivist society, which is what exists in most low and middle income countries (LMICs). I believe that the social model of understanding disability is also inadequate for a biblically informed community.

At its best, a collectivist approach to disability would not so much fear dependence but acknowledge it as a normal part of life and something that can bring value and respect to the individual. For example, we recently undertook a disability measurement study in India - a 
country that can be described as collectivist. It involved asking key informants from the community to identify those with disability. We then used our own self-assessment disability measurement tool. Many of those identified as disabled through key informants, especially the elderly, did not have a disability when they assessed themselves. This was because their functioning in society was not impaired by their old age loss of physical function, but was instead accommodated by family and the community. A friend from the field commented insightfully that for many Indians the "endpoint of striving for independence and autonomy is actually loneliness!" Vanier would go even further, concluding that "isolated we die." He says:

But of course people cannot live in isolation and in such extreme individualism. Everybody needs friends or companions. A certain togetherness or belonging.....is an integral part of the human nature. ${ }^{8}$ Dependence on each other, that is interdependence, can build community, increase social interactions, and, therefore, can promote emotional wellbeing.

I have recently proposed that a new model needs to be considered. ${ }^{9}$ It is a model which goes beyond the medical, charitable, or social frameworks and which views community and friendship as essential to both the provision of services and to the ultimate wellbeing of those with disability. This model, which I have named the interdependence model, values community and inter-reliance as a goal of disability work. Such an alternative perspective challenges the underpinnings of disability care in the west; I believe it should challenge the way we as Christians interact with disability in the global disability sector. For those who work in disability and rehabilitation, this model should change how we think about our interventions, service delivery, and program goals.

Such interdependence, which gives this model its name, is not merely functional interdependence, but also the interdependence that exists between friends. In support of this model of disability, the Lausanne Movement Cape Town Commitment captures the importance of going beyond a merely social model and encourages friendship: ". . . both in society and in the Church. God calls us to mutual friendship, respect, love, and justice. $" 10$

This is what Jeff McNair touches upon in his article in this edition entitled "Disability and Human Supports" where he explains that government social services, where workers are paid to be caring, can never be defined as friendship. Friendship cannot be defined as charitable acts where we associate with a person with disability in response to their need. That is not friendship but charity. Friendship by definition is bi-directional and interdependent.

The interdependence model privileges the idea that a person with disability exists in a community to which they contribute and from which they receive assistance. Without this community and without including the vulnerable we hurt ourselves and our community. We all lose. Typically, the dependence of those with disability is often physical, and perhaps the dependence of those without disability might be more emotional or spiritual. For example, my five year old daughter Abby has a profound intellectual and physical disability, and she is entirely dependent on my wife and me and on medical interventions to survive. However, in terms of my spiritual and emotional growth over the past five years, I think I have been more dependent on her than any other person or thing in my life. That is, my daughter and I are truly interdependent. I would not be the person I am and not fulfill my potential without her ministering to me. And for the Church, the "seemingly weaker parts are indispensable" (1 Corinthians 12:22, NIV), and these make the Church a "place of belonging; it is a place of love and acceptance; it is a place of caring; it is a place of growth in love" whereas "Individualism and materialism lead to rivalry, competition and the rejection of the weak." ${ }^{\prime \prime}$ Perhaps our focus on promoting autonomy ultimately devalues and decreases the wellbeing of a person with disability or may even lead to rejection. 
From a Christian or biblical perspective, I believe that the ultimate endpoint in disability care is more aligned with that of a non-western collectivist perspective. The Body of Christ is one that is interdependent. A biblical model needs to go beyond just changing society to accommodate for people with disabilities: It needs to move towards acknowledging that they play an important part in our community and indeed in our Church. The interdependence model is a picture of a healthy Church. We each rely on each other. There is love and friendship between all parts. We build each other up. We live together and care together. We work together and are ultimately more effective in our mission. All of us, with and without disabilities, need the love, care, and acceptance of others in the community of Christ. This community is vividly described in the Bible in 1 Corinthians 12:12-28. When each part plays its role and depends on each other, we are a truly healthy, a more biblical and a better society. The Cape Town commitment supports Paul's imagery in 1 Corinthians by means of the following:

We encourage church and mission leaders to think not only of mission among those with a disability, but to recognize, affirm and facilitate the missional calling of believers with disabilities themselves as part of the Body of Christ. ${ }^{10}$

In terms of Church inclusion this is the ultimate endpoint that I think we should aim for in our health programs and churches. Our mission and the mission of the Church is not primarily to provide comfort or good teaching, although this is important, but it is to be outwardly focused, to be reaching out with the love of Christ as in Luke 14:13. If we are to be effective in that mission then we need to allow every part of the Body to contribute. Those with disability have a calling as part of this Body.

This interdependence model could be easily rolled out through churches across LMICs to promote wellbeing and spiritual health. High cost technological and medical approaches to disability compounded by poverty are often expensive and out of reach of many with disability. Yet, the interdependence model which can be undertaken at low cost by all Christians, can be easily adopted by church congregations and health missions. This model accepts that people with disability can be healthily dependent upon family, community, and church. Whilst this must not be used as a relativist justification to deprive people of expensive aids and appliances, it does not make these items indispensable for wellbeing. Similarly, I acknowledge the importance of autonomy for a person with disability and the useful aids and procedures to promote it. However, for any of us, independence is not healthy when it impedes our interdependence within the Body and our dependence on Christ. Independence is not the ultimate aim or endpoint for us who believe in the body of Christ on this earth.

In a world with increasing numbers of people with disability and incurable diseases, and where those with disability are increasingly from low resource settings, churches and Christians in global health need to not only provide services but also reach out and include those with disability. We need to promote the dignity and value of those with disability as created in God's image and ultimately a mutuality and friendship between every part of the body of Christ. That is the interdependence model. Yet, such an approach could be costly, as it challenges existing structures, biases, and traditional roles in the modern church and our Christian global health organizations. It may turn the Church upside down, whereby the seemingly weaker and foolish things ("thing that are not") shame the wise ("things that are") (1Corinthians 1:27-28, NIV). Yet, I believe that diversity and interdependence in our Church and our global health movement is a foretaste of heaven. It's a picture of the great banquet (Luke 14).

\section{References}

1. WHO. WHO Director General's message on the International Day of Persons with Disabilities. 2014 [IDPD, 2014] 2015 [ [cited 2015 Aug 26]. Available from: http://www.who.int/disabilities/en/ 
2. UN. Convention on the rights of persons with disabilities. 2006 [cited 2015 Aug 26]. Available from:

http://www.un.org/disabilities/convention/conventio nfull.shtml

3. United Nations. Transforming our world: the 2030 agenda for sustainable development. A/RES/70/1. 2015. Available from: https://sustainabledevelopment.un.org/post2015/tran sformingourworld

4. James SN, Grills N, and Varghese J. Engage Disability Conference report. Christian Journal for Global Health. May 2015;2(1):75-9. Summary available at

https://www.youtube.com/watch?v=wUDVKse205A

5. Joni \& Friends International Disability Center. Beyond suffering advanced studies: a Christian view on disability and healthcare. Available from: http://www.joniandfriends.org/BYS/
6. Drum C. Models and approaches to disability. In: Drum CE, Krahn GL, Bersani H editor. Disability and public health. Washington DC: APHA; 2009. p. 29.

7. The moral model, referred to by McNair in his article in this issue, is one that is seen rarely in modern western societies, but it still plays a role in non-western societies and is one that the Church needs to fight to overcome.

8. Vanier J. Community and growth: St Paul's Press; 1991.

9. Grills N, In preparation.

10. Birdsall D, Brown L. The Cape Town commitment: a confession of faith and a call to action. [Movement L, editor]. : Hendrickson Publishers; 2011. p.44

Competing Interests: None declared. Dr. Grills is Associate Editor of CJGH

Correspondence: Nathan Grills, University of Melbourne, Australia. nathangrills@gmail.com

Cite this article as: Grills N. Interdependence: a new model for the global approach to disability. Christian Journal for Global Health (Nov 2015), 2(2): 1-4.

(C) Grills N This is an open-access article distributed under the terms of the Creative Commons Attribution License, which permits unrestricted use, distribution, and reproduction in any medium, provided the original author and source are properly cited. To view a copy of the license, visit http://creativecommons.org/licenses/by/3.0/

www.cjgh.org

Nov 2015. Christian Journal for Global Health, 2(2):1-4. 